\title{
Methods to study degradation of ruminant feeds
}

\author{
Ruba Mohamed and Abdul Shakoor Chaudhry* \\ School of Agriculture, Food and Rural Development, Newcastle University, Newcastle upon Tyne NE1 7RU, UK
}

\begin{abstract}
Ruman degradation is crucial in the supply of dietary nutrients to meet the nutrient demands of the anaerobic microbes and body tissues of ruminant animals. Therefore, it is essential to study the dynamics of rumen degradation of various feeds before their potential use to formulate nutritious diets for ruminant animals. Amongst many methods that have been used in the past, the in sacco method has been the most effective method to study rumen degradation. However, this method is undesirable due to its implications for animal welfare and costs. While many in vitro methods have been tested as possible alternatives to the in sacco method to study rumen degradation of feeds, they were unable to remove the need to use fistulated animals to obtain rumen fluid. Although solubility, enzyme- and faeces-based in vitro methods do not require rumen fluid, they still need data from either the in sacco method or the rumen fluid-based in vitro methods for comparison and validation. Therefore, there is a need to develop in vitro methods that do not require the need to surgically modify ruminants to obtain rumen fluid to study rumen degradation. We review the potentials and problems associated with the existing methods to study rumen degradation and their implications for the animal industry in different situations.
\end{abstract}

Rumen degradation: Animal feed: In vivo method: In sacco method: In vitro method

\section{Introduction}

Feeds when ingested by ruminant animals are subjected to microbial degradation in the rumen. The endproducts of the degradation process, i.e. ammonia, amino acids, peptides and volatile fatty acids, are utilised for the synthesis of microbial biomass. The feed escaping rumen degradation, endogenous protein and the microbial biomass entering the duodenum are used to supply energy and protein for the ruminant tissues. Therefore, the nutritional value of a feed depends on its nutrient contents, the extent of rumen degradation and the digestibility of undegraded feed components, especially protein, passing to the small intestine. Ruminants require a dietary supply of protein, sugars, starch and non-structural polysaccharides for the maintenance and synthesis of microbial biomass which is the major protein source needed for their growth and development.

To assess the nutritional status of ruminant animals, rumen degradation of feeds that they receive must be estimated. Here, a good nutritional status is defined as the one where daily nutrient intake matches the daily needs of an animal. For this purpose, a routine method to predict nutrient degradation of feeds in the rumen is needed to formulate animal rations to supply required amounts of ruminally degraded and undegraded nutrients. Therefore, all new feeding systems ${ }^{(1-3)}$ for ruminants emphasise on quantifying the ruminal degradation of feeds more precisely and accurately. However, accurate measurement of degradability is a major problem in the practical implementation of any new feeding system for ruminants. Degradability of various feedstuffs can be determined either from measuring the quantity of nutrients flowing to the duodenum or abomasum of fistulated animals (in vivo) or from the measurements of DM or $\mathrm{N}$ disappearance from synthetic porous bags suspended in the rumen of fistulated animals (in sacco or in situ). The in vivo method is laborious, expensive, requires large quantities of feed and is largely inappropriate for single feedstuffs, thereby making it unsuitable for routine feed evaluation. The in vivo method is also subject to errors associated with the use of digesta flow-rate markers, microbial markers and inherent animal variations $^{(4)}$. The in sacco method, in which the synthetic fibre bags, containing test feeds, are incubated in the rumen for various periods of time has been useful for many years ${ }^{(5,6)}$ to evaluate feedstuffs for DM and $\mathrm{N}$ degradation and particle outflow rate. However, the reproducibility among laboratories for this method is poor partly due to the variation in proteolytic activity between animals due to their variable diets and physiological status, etc. Therefore the results obtained for this method may not be equally applicable to all situations unless the method is standardised for a common protocol. As the in sacco method requires surgically prepared

\footnotetext{
Abbreviations: ARF, autoclaved rumen fluid; BMM, Burroughs' mineral mixture; CP, crude protein; ECPD, effective crude protein degradability; NPN, non-protein N; RDP, rumen-degraded protein; UDP, undegradable dietary protein.

* Corresponding author: Dr Abdul Shakoor Chaudhry, fax +44 191222 6720, email a.s.chaudhry@ncl.ac.uk
} 
animals, it is undesirable on animal welfare grounds and has associated costs, and so only a limited sample size and numbers can be examined at a time, especially in sheep.

There has been a great interest in developing a cheap and convenient alternative in vitro method to obtain estimates for rumen-degraded and-undegraded feeds in order to balance animal rations ${ }^{(7)}$. These alternatives include solubility in various solvents ${ }^{(8-10)}$ and the gas production technique ${ }^{(11-12)}$, which has been criticised for using the fermentation gas, a nutritional waste product, to evaluate feedstuffs. While gas release is closely related to feed degradation, it does not directly represent the extent of degradation. In fact, feedstuffs with a low rate of gas production may have a higher in vivo digestibility than suggested from gas production ${ }^{(11)}$. This could be due to the added post-rumen activities that only occur during the in vivo digestion of a feed. Researchers have also used enzymes for the determination of in vitro degradation of feedstuffs ${ }^{(13-15)}$. However, due to microbial conversions in the rumen, the amount of protein supplied in the diet and its subsequent absorption by the animal (in vivo) is less predictable by using commercial enzymes ${ }^{(16)}$. Consequently, it is not possible to identify any enzyme that will rank the feedstuff in the same order as the in vivo method.

The use of rumen fluid for in vitro incubation of feeds is well established since its use by Tilley \& Terry ${ }^{(17)}$. However, rumen fluid for such incubations is still usually obtained from rumen-fistulated animals, which is undesirable as described above. Therefore, alternative methods are required for the estimation of rumen degradation of various feeds without involving surgically prepared animals. The present review examines the importance of studying the mechanisms of rumen degradation by involving various methods and their suitability and implications for the systems of feeding ruminants. The present review also explores the potentials and problems that may exist in the development of alternative in vitro methods and their ultimate application for the feed and animal industry.

\section{Importance of the reticulo-rumen in degradation of feeds}

The rumen (sometimes regarded as the reticulo-rumen) holds about $80 \%$ of the total digesta ${ }^{(18)}$. It contains microorganisms that are particularly effective in fibre digestion and so enables ruminants to survive under poor-quality nutritional conditions. The rumen is considered as a continuous anaerobic fermenter that is maintained at constant temperature. Saliva enters continuously and provides appreciable buffering through its contents of phosphate and bicarbonates. The feed is fermented by the action of micro-organisms to yield mainly the volatile fatty acids, carbon dioxide $\left(\mathrm{CO}_{2}\right)$ and methane $\left(\mathrm{CH}_{4}\right)$. The major energy source of the host animal is provided by volatile fatty acids, while its amino acid supply is derived from the breakdown of microbial and undegraded feed protein passing into the small intestine.

Numerous bacteria and protozoa are present in the rumen (about 1 billion bacteria and 1 million protozoa per $\mathrm{ml}$ rumen fluid). Endproducts of fermentation are absorbed continuously, which help to maintain an environment conducive for the microbial growth in the rumen. McDonald et al. ${ }^{(19)}$ reported over sixty species of bacteria which are mostly non-spore-forming anaerobes. Protozoa are present in small numbers but, being larger in size than bacteria, they are almost equal in total mass to bacteria. Rumen fungi have also been reported to play an important role in the degradation of ruminant feeds within the rumen ecosystems ${ }^{(20-22)}$. The ruminant animals can derive various nutrients from ingested feeds with the help of these microorganisms. However, their ability to degrade proteins and other nutrients to obtain $\mathrm{N}$ and energy supply to maintain rumen function and tissue growth is particularly important and so the protein degradation receives special attention in the following sections.

\section{Rumen degradation and nutrient requirements}

The nutrient requirements of ruminants are mostly dependent on their stages of growth and production levels. As with non-ruminants, the animal must absorb essential amino acids from the small intestine. However, ruminal micro-organisms are capable of synthesising most of the common amino acids. Therefore, ruminants have the unique ability of their micro-organisms to convert non-protein $\mathrm{N}$ (NPN) in association with energy supply to protein, and so these animals can survive by maintaining themselves while consuming only NPN-based diets. Nonetheless, microbial protein synthesis alone is not adequate to maintain the high levels of production of modern ruminants ${ }^{(23)}$. Therefore, some feed protein that can escape ruminal degradation is required in ruminant diets. This protein is classed as 'undegradable dietary protein' (UDP) in some feeding systems ${ }^{(1)}$ when formulating ruminant diets. The protein that is degraded in the rumen is classed as 'rumen-degraded protein' (RDP). RDP is composed of both quickly degradable protein and slowly degradable protein.

UDP has been demonstrated to be required for maximal growth of beef steers ${ }^{(24)}$. The amount of amino acid absorbed in the small intestine was greater for cattle fed diets containing a greater portion of UDP relative to RDP. In these diets the rumen ammonia levels were lower for the high-UDP diets. In addition, infusion of amino acid directly to the small intestine also increased DM intake and production, thus demonstrating the importance of UDP entering the small intestine ${ }^{(23,25)}$.

Although provision of dietary protein that escapes ruminal degradation is important for optimising production of high-producing ruminants, feeding to increase microbial protein may also increase the flow of essential amino acids to the small intestine. Microbial growth requires an adequate supply of carbohydrates that are fermented in the rumen, and a rumen environment conducive to microbial growth. Microbial growth may be limited if carbohydrate degradation is too low to supply the energy for microbial activity. Alternatively, on high-starch diets, the $\mathrm{pH}$ of the rumen fluid will decrease which will lower microbial growth $^{(26)}$. The interactions of these factors result in a limit to the maximal amount of protein synthesis that can occur in the rumen.

Microbial protein synthesis is mostly limited by the amount and form of $\mathrm{N}$ available to rumen organisms ${ }^{(27)}$. 
Inadequate RDP supply may result in a decrease in protein entering the small intestine due to a depression of microbial protein synthesis. If inadequate $\mathrm{N}$ is available to rumen microbes, fibre digestion may also be reduced ${ }^{(28)}$. When microbes are not available to digest fibre in forages, fibre has a greater filling effect, and hence feed intake can be reduced $^{(29)}$. Therefore, while it is important to supply an adequate amount of UDP to help meet the needs of the host animal, there is also a requirement for RDP to maintain microbial growth to synthesise microbial protein, degrade dietary fibre, and promote rumen function.

While most of the nutrient needs of rumen microorganisms are met with ammonia and carbohydrates, microbial growth is maximised by the inclusion of amino acids or peptides in the rumen ${ }^{(30)}$. In vitro studies involving incubation of rumen fluid with amino acid mixtures showed that maximal microbial growth was obtained by supplementation of urea with a mixture of leucine, methionine and histidine ${ }^{(31)}$. Addition of other amino acids did not result in further increases in microbial growth. Ruminal infusion of casein or supplementation with soyabean meal increased microbial protein synthesis in the rumen above that observed with the urea infusion ${ }^{(26)}$. Supplementation with soyabean meal or fishmeal gave greater fibre digestion than supplementation with urea ${ }^{(28)}$. This suggests that amino acid-containing protein meals can improve cellulolytic activity of rumen microbes more that the NPN sources alone.

Accurate formulation of ruminant diets requires attention to the protein and energy interactions. As mentioned earlier, the amount of microbial protein synthesis depends partly on the ruminally available carbohydrate to support microbial growth. Therefore, the amount of RDP required in a ration depends on the level of ruminally available carbohydrate. A study showed faster disappearance of soyabean meal and sunflower-seed meal from nylon bags suspended in the rumen when sheep were fed dried grass instead of a barleybased diet with little fibre ${ }^{(32)}$. This suggests that nutrient degradation may be affected by the type of carbohydrate and fibre in the ration.

If $\mathrm{N}$ available to micro-organisms limits microbial growth, then there may be an advantage in increasing RDP in the rumen. However, once the microbial requirements for RDP have been met, there is no additive effect of additional rumen $\mathrm{N}^{(33)}$. The excess RDP is converted to ammonia in the rumen and diffuses to the blood. In the same way, if the UDP requirement has been met, and no amino acids are limiting, there is no advantage in further increasing the amount of UDP in the diet beyond the effect of providing additional energy. In fact, Chaudhry ${ }^{(34)}$ did not find any positive effect of adding casein, urea and xylose on the in vitro digestibility of barley straw when incubated with the rumen fluid from well-nourished sheep. Understanding these possible effects and interactions of rumen protein availability makes it easier to understand why studies often fail to show the positive and combined effects of balancing rations for UDP and RDP. The requirements for each type of protein may depend on other feeds in the diet, and an effect will not be seen unless the level of UDP or RDP (quickly degradable plus slowly degradable proteins) is limiting production.
The only way to be certain to have met the requirements for UDP and RDP when balancing a ration is to supply these protein fractions in excess. However, there are several reasons why feeding excess protein to high-producing ruminants is undesirable, especially due to the higher cost of protein-containing ingredients. Therefore, optimisation of the level of protein ingredients in ruminant diets is important to the profitability of farms. Otherwise, excess dietary protein results in high levels of blood urea and ammonia, which could be toxic to the tissues and may result in an impaired reproductive performance ${ }^{(35)}$, and increased nitrogenous wastes which could harm the natural water supply and the environment ${ }^{(36)}$. Therefore, excess dietary protein for ruminants is not adequate, so a better understanding of the amounts of different types of nutrients that are required in rations for their utilisation in the rumen is needed. This can be achieved by involving studies that partition dietary proteins into rumen degradable and nondegradable fractions. Researchers have used various methods in the past to study rumen degradation of animal feeds and the following sections summarise the advantages and disadvantages of some of these methods.

\section{Methods for estimating rumen degradation of feeds}

Currently, numerous methods involving different procedures are available for estimating degradation of feeds. For example, the in vivo methods involve markers and the in sacco method requires animals that are surgically modified with rumen cannulae. The in vitro methods require the use of rumen fluid, which is obtained from fistulated animals, to estimate either digestibility ${ }^{(17)}$ or gas production $^{(11,12)}$. There are other in vitro methods that involve proteolytic enzymes which are either commercially extracted from non-rumen sources (for example, ficin from fig latex or sap or protease from Streptomyces griseus) or extracted from mixed rumen micro-organisms ${ }^{(37,38)}$. A range of in vivo, in sacco and in vitro methods that are being used are therefore described in the following sections.

\section{In vivo methods involving internal and external markers}

In vivo methods are the most logical to evaluate degradation of feeds in the rumen. The protocols require animals fitted with cannulae in the reticulo-rumen, the abomasum, or proximal duodenum ${ }^{(4,39)}$. Also they require suitable methods for determining digesta flow rates and for differentiating microbial protein from dietary protein in the digesta that flows to the small intestine. These procedures are labour intensive and require considerable investment. In addition, increasing concern for animal welfare limits the applicability of such methods. For these reasons, only a few animals can be used in in vivo experiments, which could be unreliable due to the large variation observed among animals ${ }^{(4)}$. The in vivo procedure also relies on the accurate estimation of the flow of microbial protein to differentiate it from the feed protein reaching the duodenum. For this purpose several microbial markers have been used. These may be classified as internal markers that are inherently present in micro-organisms and include diaminopimelic acid, aminoethylphosphonic acid 
and nucleic acids (DNA or RNA) or external markers (that are added to the rumen to label the micro-organisms) including ${ }^{35} \mathrm{~S},{ }^{15} \mathrm{~N},{ }^{14} \mathrm{C},{ }^{3} \mathrm{H}$ and ${ }^{32} \mathrm{P}$, etc. Despite the use of several markers, there is no single ideal marker to estimate the ruminal microbial protein yield ${ }^{(40)}$.

There is a need for a more practical, repeatable and cheaper method for measuring ruminal degradation of various feeds, particularly for commercial laboratories which do not have access to fistulated animals. In spite of the limitations with the in vivo procedure, a routine alternative procedure would only be acceptable following validation against in vivo measurements. Different investigators have used several alternative procedures but without reaching a consensus on the suitability of a unified approach.

\section{In sacco method to estimate feed degradation}

The in sacco technique was first suggested by Quin et al. ${ }^{(41)}$ and it has since been used by others to estimate utilisation of either forages ${ }^{(42)}$ or concentrates and high-protein feeds ${ }^{(5)}$. Interest in the technique has intensified since Mehrez \& $\emptyset_{\text {rskov }}{ }^{(5)}$ critically assessed the factors causing variability in DM and $\mathrm{N}$ degradability. They concluded that as long as the bags were large enough to allow free movement of substrate within, the technique could be extremely useful as a rapid guide to determine nutrient disappearance, particularly the rate and extent of nutrient disappearance from the rumen. All modern systems of feeding ruminants $^{(1,2,43)}$ require an estimation of the amount of feed protein escaping ruminal degradation. This estimation is obtained by the in sacco technique, which is probably the best-known simple and reliable method to assess the degradability of DM and protein in the rumen ${ }^{(1-3,5,43)}$.

The in sacco method requires the use of fistulated animals, which limits its routine use by the commercial laboratories. However, it is widely applied by researchers since it requires fewer measurements, is relatively less labour intensive and so is cheaper as compared with the in vivo method. The in sacco method involves the sealing of feed samples within nylon, polyester or Dacron bags, which are then suspended in the rumen of sheep or cattle for varying periods of time, followed by determination of the $\mathrm{DM}$ and protein in the washed residues. The technique allows the test feed to be incubated in the ruminal environment (i.e. $\mathrm{pH}$, temperature and $\mathrm{CO}_{2}$ ), but unlike the normal situation the feed is not subjected to mastication and rumination. Despite its widespread use, the technique has inherent errors that must be taken into account, particularly if comparisons of degradation among different laboratories are to be made. Table $1^{(44-47)}$ shows possible sources of variations in the use of the in sacco method among different laboratories in terms of bag size, sample size, particle size and time (h) of incubation used by different authors. The assumption that the $\mathrm{N}$ leaving the bag during washing in water, at $0 \mathrm{~h}$ of incubation, is completely degraded may not be true ${ }^{(10,48)}$. Extensive loss of feed material at 0 time will lead to an overestimation of degradability. Although Table 1 and Table $2^{(15,49-52)}$ present information in relation to degradable crude protein values only, it is assumed that

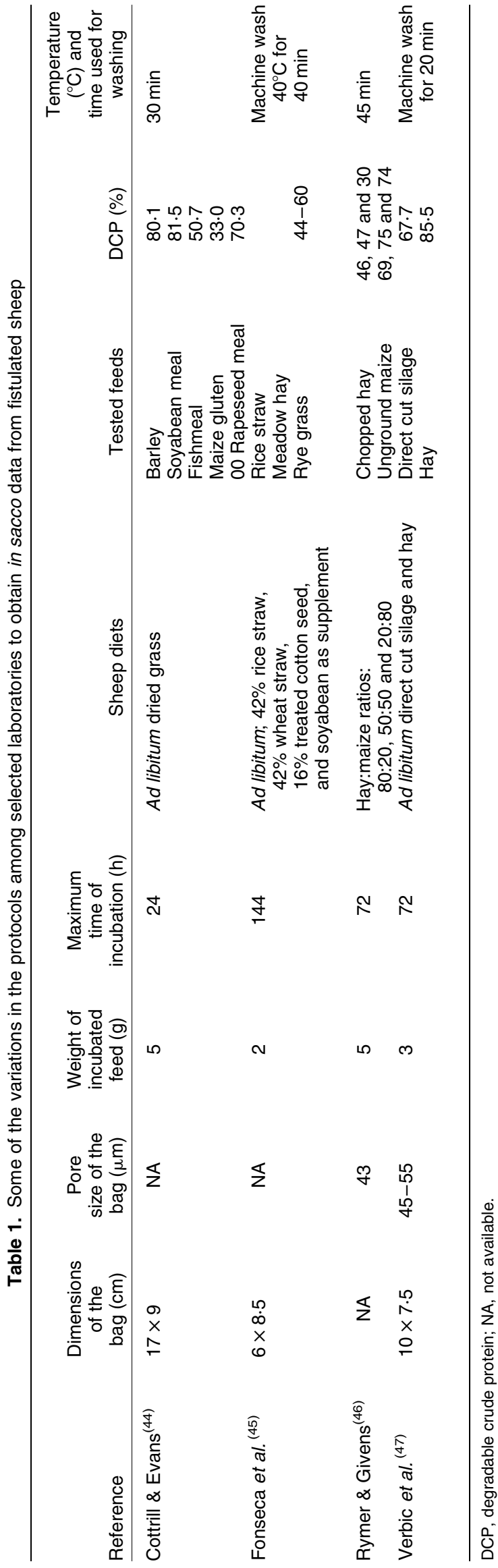


Table 2. Some of the variations in the protocols being used by different laboratories to obtain in sacco data using fistulated cattle

\begin{tabular}{|c|c|c|c|c|c|c|c|c|}
\hline Reference & $\begin{array}{l}\text { Bag dimension } \\
(\mathrm{cm})\end{array}$ & $\begin{array}{l}\text { Bag pore } \\
\text { size }(\mu \mathrm{m})\end{array}$ & $\begin{array}{l}\text { Weight } \\
\text { of incubated } \\
\text { feed }(\mathrm{g})\end{array}$ & $\begin{array}{c}\text { Maximum } \\
\text { incubation } \\
\text { time }(\mathrm{h})\end{array}$ & Cattle diets & Tested feeds & DCP (\%) & $\begin{array}{c}\text { Washing } \\
\text { temperature } \\
\left({ }^{\circ} \mathrm{C}\right) \text { and time }\end{array}$ \\
\hline Chaudhry ${ }^{(15)}$ & $20 \times 10$ & $40-50$ & 10 & 24 & Hay + concentrate & $\begin{array}{l}\text { Field beans } \\
\text { Maize gluten meal } \\
\text { Distiller's dark grains } \\
\text { Sunflower-seed meal }\end{array}$ & $\begin{array}{l}83 \\
23 \\
74 \\
85\end{array}$ & $\begin{array}{l}\text { Machine wash for } \\
15 \mathrm{~min}\end{array}$ \\
\hline De Smet et al. ${ }^{(49)}$ & $8 \times 8$ & 50 & 2 & 48 & $\begin{array}{l}\text { Ad libitum } 55 \% \text { maize } \\
\text { silage and } 45 \% \\
\text { compound feed }\end{array}$ & $\begin{array}{l}\text { Barley } \\
\text { Wheat } \\
\text { Maize } \\
\text { Sorghum } \\
\text { Sugarbeet pulp } \\
\text { Soyabeans }\end{array}$ & $\begin{array}{l}55 \cdot 5 \\
73 \cdot 9 \\
52 \cdot 0 \\
20 \cdot 5 \\
39 \cdot 6 \\
34 \cdot 0\end{array}$ & $\begin{array}{l}\text { Machine wash for } \\
10 \mathrm{~min} \text { and } \\
\text { rinsed } 10 \mathrm{~min}\end{array}$ \\
\hline Djouvinov et al. ${ }^{(50)}$ & $9 \times 14$ & 16 & 3 & $\begin{array}{l}24(C) \\
72(S)\end{array}$ & $\begin{array}{l}\text { Two equal portions } / \mathrm{d} \\
4 \mathrm{~kg} \text { lucerne hay, } \\
4 \mathrm{~kg} \text { meadow hay } \\
\text { and } 1 \mathrm{~kg} \text { barley }\end{array}$ & $\begin{array}{l}\text { Barley } \\
\text { Grass } \\
\text { Wheat bran } \\
\text { Brewer's grain } \\
\text { Soyabean meal } \\
\text { Sunflower meal } \\
\text { Fishmeal }\end{array}$ & $\begin{array}{l}49 \cdot 4 \\
71 \cdot 6 \\
71 \cdot 3 \\
48 \cdot 2 \\
76 \cdot 5 \\
70 \cdot 2 \\
28 \cdot 4\end{array}$ & $\begin{array}{l}\text { Machine wash for } \\
10 \mathrm{~min}\end{array}$ \\
\hline Kristensen et al. ${ }^{(51)}$ & $7.5 \times 10$ & 36 & 1 & 48 & Ad libitum hay & $\begin{array}{l}\text { Soyabean meal } \\
\text { Cotton-seed meal } \\
\text { Fishmeal }\end{array}$ & $\begin{array}{l}73 \\
73 \\
50\end{array}$ & $\begin{array}{l}\text { Washed manually } \\
\text { under tap water } \\
40^{\circ} \mathrm{C}\end{array}$ \\
\hline Noziere \& Michalet-Doreau ${ }^{(52)}$ & $5 \times 9 \mathrm{~cm}$ & 53 & 3 & 23 & $\begin{array}{l}7 \mathrm{~kg} \mathrm{DM} / \mathrm{d} \\
57 \% \text { grass hay, } \\
12 \% \text { wheat straw, } \\
31 \% \text { barley pellets }\end{array}$ & $\begin{array}{l}\text { Two grass hays: } \\
\text { Regrowth } \\
\text { Late harvested }\end{array}$ & $\begin{array}{l}55-60 \\
35-45\end{array}$ & $\begin{array}{l}\text { Washed manually } \\
\text { in salt solution }\end{array}$ \\
\hline
\end{tabular}


similar variations in practice will also cause variations in DM and organic matter degradability values.

Beside microbial contamination within the bag, there are numerous other sources of errors that affect the in sacco DM and $\mathrm{N}$ disappearance from feeds. The importance of sample weight in a given bag size has been emphasised by Bullis et al. ${ }^{(53)}$ who observed reduced DM digestibility with increased weight in the bag. This finding agreed with the finding of Van Keuren \& Heineman ${ }^{(42)}$ who showed that sample weight influenced DM digestibility, at least when short incubation times were used; the difference tended to disappear with longer periods of incubation. Also, oven drying of silage samples at high temperatures was found to reduce $\mathrm{N}$ degradability and solubility ${ }^{(54)}$ of these samples. Additionally, Noziere \& Michalet-Doreau ${ }^{(55)}$ reported that grinding and pre-wetting underestimates degradation rates due to the increased microbial colonisation. Machine washing of residues overestimates solubles and particulate losses but it is less subjective than hand washing ${ }^{(56)}$. Huntington \& Givens ${ }^{(57)}$ reported that bag pore size less than $15 \mu \mathrm{m}$ can reduce degradation by restricting microbial colonisation and diversity and trapping fermentation gases. However, bag pore size of more than $40 \mu \mathrm{m}$ can cause losses of solubles and undegradable particles. Furthermore, the animal effects and bag incubation sequence also contribute to the variation in results among laboratories ${ }^{(58)}$.

The disappearance of DM is also affected by the diet fed to the host animal ${ }^{(59)}$. While these effects make it difficult to compare feeds for degradation across studies, DM or protein degradation of a feed is not entirely a function of the feed, but also affected by the ruminal conditions, so variation across studies is expected. More troublesome aspects of the in sacco method do exist. The $\mathrm{pH}$ inside the nylon bag has been shown to be lower than that outside the bags, especially when small pore-sized bags were used ${ }^{(60)}$. The microbial population inside the bags also differed, both in composition and concentration, from that of the outside of the bag. For example, both protozoa and bacterial populations were found to be lower inside the bags ${ }^{(60-61)}$. This could be due to the limited micro-environment that existed within the bag involving a single ingredient of smaller size with limited exposure to rumen microbes perhaps due to the bag size and its pores.

Analysis of digesta from nylon bags incubated in vitro showed that some nutrients escaped the nylon bags before being digested ${ }^{(62)}$. The microbial attachment to feeds incubated in sacco is frequently not measured, though several studies have shown high levels of contamination of incubated feed with rumen microbes ${ }^{(57)}$. All these sources of errors increase variability of predictions of degradability among laboratories. In spite of being widely used and standardised, the application of this methodology needs to address two points: first, the fraction assumed to be completely degraded, and the DM and $\mathrm{N}$ disappearance during this step could simply be due to DM or $\mathrm{N}$ washed out of the bag; second, the microbial contamination of feeds within the bags. The first point would overestimate degradation and the second point would underestimate it ${ }^{(63)}$. The significance of these two factors would be important depending on the type of feed being analysed. However, the in sacco method is still the reference method in most countries; the reason is probably that the degradability is measured in the rumen and, therefore, from a biological point of view it is more reliable than those of the in vitro methods ${ }^{(64)}$. But as in vivo and in sacco methods require fistulated animals they cannot be accepted as methods for routine screening of feedstuffs. Therefore, there is a need for a viable and accurate in vitro method to estimate the degradability of feeds in the rumen.

Tables 1 and 2 indicate some of the variations of the most commonly tested methods using fistulated sheep or cattle, i.e. the same feeds give different values in different laboratories. For example, Cottrill \& Evans ${ }^{(44)}$ reported effective crude protein (CP) degradability $(\mathrm{ECPD}=a+(b \times c / c+k)$, where $c$ is degradation rate of $b$ and $k$ is rumen outflow rate) in fistulated sheep of 51 and $82 \%$ for fishmeal and soyabean respectively. In an unrelated study, Djouvinov et al. ${ }^{(50)}$ used fistulated cattle and reported ECPD of 28 and $77 \%$ for fishmeal and soyabean respectively. In contrast, Kristensen et al. ${ }^{(51)}$ used fistulated cattle and reported ECPD of 50 and $73 \%$ respectively for different samples of the same feeds. Tables 1 and 2 show that different amount of feeds were incubated using various dimensions of bags in each of the above three studies. Additionally, Cottrill \& Evans ${ }^{(44)}$ reported ECPD of $33 \%$ for maize using fistulated sheep compared with $52 \%$ reported by De Smet et al. ${ }^{(49)}$ for another sample of maize using fistulated cattle. On the other hand, variation was also observed in ECPD for cattle where variable ECPD of 28 v. $50 \%$ for fishmeal were reported by different authors ${ }^{(50-51)}$. Similar variations for the ECPD of 34 v. $77 \%$ for soyabean meal were also reported ${ }^{(49-50)}$. This clearly shows the inconsistency between laboratories which may be because different diets offered to the same host animal have different effects on degradability of the same feed. Additionally, different time (h) of incubation, different sample size and different dimension of in sacco bags gave different degradability values for the same feeds. Nevertheless, Table $3^{(65)}$ presents variation in the in sacco ECPD results for the same feed in the same laboratory. Madsen \& Hvelplund $^{(65)}$ reported different values for feeds using fistulated cattle. In their study they tested a minimum of three samples for the same feed obtained from different sources and the ECPD was calculated as the average of all values obtained. Table 3 shows the variations that could occur in the in sacco method for the same feed, although feeds were

Table 3. Variation in the in sacco data for the same feed within the same laboratory ${ }^{(65)}$

\begin{tabular}{lcc}
\hline Feeds & CP in DM (\%) & ECPD (\%) \\
\hline Barley & 12.9 & 74 \\
Barley & $12 \cdot 1$ & 60 \\
Fishmeal & 75 & 53 \\
Fishmeal & 77 & 22 \\
Peas & 22.9 & 80 \\
Peas & 23.2 & 73 \\
Cotton seed & 44.2 & 62 \\
Cotton seed & 44.3 & 39 \\
Soyabeans & 40.5 & 81 \\
Soyabeans & 35.3 & 66 \\
Maize & 9.8 & 33 \\
Maize & 9.8 & 26
\end{tabular}

$\mathrm{CP}$, crude protein; ECPD, effective crude protein degradability. 
selected on the basis of their almost similar CP contents in DM. These variations could partly be attributed to the differences in variety, agronomic conditions and processing methods to obtain these feeds. Such variations in the in sacco estimates raise the question: when formulating a ration for ruminants, which of the reported values should be followed? This question necessitates the need to either standardise the in sacco method by following a standard protocol with minimum sources of variations or more preferably develop alternative methods which are more consistent and which do not require the use of surgically modified animals to estimate degradability of ruminant feeds.

\section{In vitro methods to estimate nutrient degradation}

Numerous in vitro methods have been used in the past as alternatives to the in sacco method. These methods involve buffers, chemical solvents, rumen fluid and enzymes that are either commercially available or extracted from rumen contents. Another approach is to use gas production as an indirect measure of in vitro digestion. In vitro techniques are considered less expensive than the in vivo and in sacco methods, and they offer the possibility of analysing both the residue and the metabolites of microbial degradation. In contrast, more physiological techniques are complicated by the fluxes out of the rumen or out of the incubation bags. In vitro methods may ultimately allow for the control of various factors that alter the feed degradation (microbial, animal, environment) and, therefore, allow for the uniform characterisation of feeds for DM and protein degradation.

Tilley \& Terry ${ }^{(17)}$ developed an in vitro method to estimate the apparent DM digestibility of feeds for ruminants in the laboratory. The method has two stages. In the first stage, a feed sample is incubated at $38^{\circ} \mathrm{C}$ in rumen fluid, which is diluted with a buffer solution resembling saliva and saturated with carbon dioxide. After $48 \mathrm{~h}$, the incubation is stopped and the incubation mixture filtered. The feed residues are subsequently incubated for another $48 \mathrm{~h}$ with pepsin- $\mathrm{HCl}$. The main disadvantage of the method is that rumen fluid is required, which is obtained from fistulated animals, and may not be available in all laboratories. Since the use of fistulated animals is not desirable, the need for alternative in vitro methods has arisen. There are many difficulties that are associated with the in vitro fermentation studies. These include the requirements to standardise the fermentation process, measurement of fermentation profiles and the access to fistulated ruminants to obtain rumen inocula. Therefore, several methods have been developed to measure nutrient degradation by using various enzyme preparations involving cellulases, proteases, lipases and amylases individually or as mixtures. Ruminal protease was enriched from Bacteroides amylophilus and used for studies of degradation of several protein sources ${ }^{(43)}$. Alternatively, other methods have used commercially available proteases. Some of these in vitro methods are discussed in the following sections.

\section{In vitro methods involving solubility in solvents and buffers}

Several researchers have attempted to characterise feed nutrients according to their solubility in aqueous solutions such as saline and buffers, autoclaved rumen fluid (ARF) and water (cold, hot or distilled $)^{(8-10,48,66-71)}$. However, most of the available reported literature on feed solubility focuses on protein solubility. $\mathrm{N}$ solubility varies greatly for different feedstuffs. For example, while $\mathrm{N}$ of brewer's grains was only $3 \%$ soluble in borate-phosphate buffer, oat $\mathrm{N}$ was $55 \%$ soluble ${ }^{(69)}$. Buffer-soluble $\mathrm{N}$ is comprised mostly of NPN, such as ammonia, urea, nitrates, amino acids and small peptides ${ }^{(66-69)}$. Nucleic acid $\mathrm{N}$ is the major NPN fraction that is not soluble in neutral buffer, but generally it is low in quantity and it is underestimated by $\mathrm{N}$ analysis using the Kjeldahl procedure ${ }^{(72)}$. In addition to NPN, some true protein is soluble to varying degrees among feeds.

Protein solubility is influenced by various factors associated with the solvent or extraction procedure. Changes in chemical composition of solvent can have pronounced effects on $\mathrm{N}$ solubility. For example, substitution of ammonium chloride with sodium chloride in Burroughs' mineral mixture (BMM) resulted in increased $\mathrm{N}$ solubility for several concentrates ${ }^{(70)}$. It is difficult to draw meaningful conclusions as to the effect of solvent composition on $\mathrm{N}$ solubilisation, because of the interaction that may exist among feedstuffs, methodologies and solvents. For example, in one study, N solubility was found to be higher in BMM or $0.15 \mathrm{M}$-sodium chloride than in $\mathrm{ARF}^{(67)}$, whereas some researchers have reported the opposite response ${ }^{(73)}$ and others found insignificant difference among three solvents ${ }^{(74)}$. It is noteworthy that similar concentrate feeds were analysed in each of the above studies.

Comparisons of ARF, $\mathrm{NaCl}, \mathrm{BMM}$ and hot water revealed that the differences among feeds were most pronounced for ARF, suggesting that this method may best separate different feeds according to protein solubility ${ }^{(73)}$. However, while homogeneous variance within samples was detected in the above experiment, the use of ARF may not be repeatable from laboratory to laboratory, or from time to time, as ARF composition can very depending upon the diet and other biological differences between donor animals.

The $\mathrm{pH}$ of a solvent has been shown to influence $\mathrm{N}$ solubility of concentrate feed protein ${ }^{(9,73)}$. About $85 \%$ of soyabean meal protein was soluble in aqueous $\mathrm{HCl}(\mathrm{pH} 2.0)$ and water $(\mathrm{pH} \mathrm{7.2)}$, while less than $10 \%$ was soluble at $\mathrm{pH}$ $4^{(73)}$. Significant differences in solubility of isolated soyabean protein and casein were also observed when $\mathrm{pH}$ of ARF and BMM varied from $5 \cdot 5$ to $\mathrm{pH} 6 \cdot 5^{(9)}$. However, the effect of $\mathrm{pH}$ on protein solubility often is measured in neutral $\mathrm{pH}$ solutions, even though rumen fluid is slightly acidic when donor animals consume high-grain-based diets. As sodium chloride has almost no buffering capacity and bicarbonate-phosphate buffer has an unstable $\mathrm{pH}$, a borate-phosphate buffer has been suggested as an appropriate substitute to measure $\mathrm{N}$ solubility without variation due to fluctuation in $\mathrm{pH}^{(75)}$.

Buffer-soluble CP appears to be more readily degraded in the rumen than insoluble $\mathrm{N}$. There was a close association between buffer-soluble $\mathrm{CP}$ and $\mathrm{N}$ disappearance from synthetic fibre bags suspended in the rumen, especially when feeds were incubated in sacco for short periods of $1 \mathrm{~h}^{(57,71)}$. In addition, the amount of buffer-soluble $\mathrm{N}$ in a feed was correlated strongly to increases in rumen ammonia 
concentration after feeding ${ }^{(76)}$. However, other researchers found no consistent relationship between $\mathrm{N}$ solubility in various aqueous solvents and ammonia concentration $^{(68)}$. $\mathrm{N}$ that is available to microbes is converted to ammonia which is used for microbial protein synthesis which is considered as true protein due to its high amino acid profile. Soluble NPN is utilised by rumen bacteria and solubility in mineral buffer of pure proteins was correlated strongly to degradation rate in rumen fluid ${ }^{(77)}$.

Some researchers have reported a poor correlation between $\mathrm{N}$ solubility in buffer and in vivo protein degradation across several feeds ${ }^{(71)}$. This result was not surprising given that the amount of soluble feed protein appears to have no relationship with degradation rate of the remaining insoluble protein fraction of a given feed $^{(48,70)}$. Therefore, one can conclude that estimation of $\mathrm{N}$ solubility in neutral buffers may predict the amount of $\mathrm{N}$ immediately available to bacteria, but it may not be accurate for all feeds as discussed above and $\mathrm{N}$ solubility in aqueous solutions is not sufficient to determine protein degradation rate or protein degradability. However, as suggested by Chaudhry \& Webster ${ }^{(10)}$, positive correlations between some soluble protein fractions and degradation of feeds do require further investigations to test this approach for its much wider application.

\section{In vitro methods using enzymes}

Rumen digestion is mainly linked to the cellulolytic activity of the microbial flora, which represents its specificity and advantage to utilise cellulose-rich feeds. Researchers have used commercially available cellulolytic enzymes, often extracted from fungi, to reproduce this activity; hence many enzymic methods have been proposed for their use to predict feed digestibility. These methods differ on the basis of the nature and level of the enzymes and the target feeds and whether a pre-treatment (chemical or enzymic) is necessary or not ${ }^{(78)}$. These methods are widely used for forages, and have been applied to by-products, concentrates and mixed feeds produced by the agro-food industry. For various types of forages, prediction involving enzymes is higher, perhaps due to the enzyme specificity and greater activity than the chemical methods and comparable with that obtained in vitro ${ }^{(79)}$. In addition, cellulase methods can be used for mixed rations and permanent pastures. With forages containing tannins, organic matter digestibility prediction is generally poor when cellulolytic enzymes are used. This can be due to the fact that enzymes are used at $\mathrm{pH}$ values that are different from those prevailing in the rumen, enabling possible release of tannins and their subsequent linkage to protein. Another possible explanation is that some tannins might have inhibited the enzyme activity, especially on cellulose. Malestein et al. ${ }^{(80)}$ showed clear differences in starch degradation upon incubation with $\alpha$-amylase or rumen fluid. However, Cone \& Vlot ${ }^{(81)}$ concluded that it was not possible to accurately predict the rate of starch degradation by rumen fluid as with enzymic degradation. Addition of non-amylolytic enzymes, such as cellulase, protease, lipase, xylanase and pectinase, did not enhance starch degradation. Starch granules contain components other than amylose and amylopectin and possibly need non-amylolytic enzymes for full degradation. These enzymes may be found in the rumen microorganisms.

Indeed, the procedures involving the use of commercial proteases offer potential advantages over other techniques, particularly in terms of the labour and speed of operation. Proteases from different origins have been tested by several researchers to estimate ruminal protein degradation; however, the most commonly used is the one obtained from S. griseus as reported by Chaudhry ${ }^{(14,15)}$ and Krishnamoorthy et al. ${ }^{(69)}$. Table $4^{(9,13-15,69,82-87)}$ gives the list of enzymes studied in some recent publications on the topic.

CP degradation using five different commercially available proteases was compared with that of the in sacco method for several concentrate feeds ${ }^{(13)}$. The solubility of $\mathrm{CP}$ was determined by filtering after separate incubation with S. griseus protease, papain, bromelain, ficin and Aspergillus oryzae protease. Though absolute degradation with protease was different from that observed in sacco, all enzymic degradations were significantly correlated to the in sacco data, supporting the possible use of enzymes to detect relative differences among feeds for degradation. S. griseus protease has become popular for prediction of protein degradation of feeds but the optimal $\mathrm{pH}$ for the

Table 4. Summary of the selected commercial enzymes used by different authors to estimate in vitro degradation of feeds

\begin{tabular}{|c|c|c|c|}
\hline Enzyme used & $\mathrm{pH}$ & Time (h) & References \\
\hline Protease & $8 \cdot 0$ & 1 & Krishnamoorthy et al. ${ }^{(69)}$ \\
\hline \multirow[t]{8}{*}{ (Streptomyces griseus) } & $6 \cdot 7$ & $18(\mathrm{C})$ and $48(\mathrm{~F})$ & Roe et al. ${ }^{(82)}$ \\
\hline & $8 \cdot 0$ & $18(\mathrm{C})$ and $48(\mathrm{~F})$ & Licitra et al. ${ }^{(83)}$ \\
\hline & $7 \cdot 5$ & $48(\mathrm{~F})$ & Wohlt et al. ${ }^{(9)}$ \\
\hline & $6 \cdot 7$ & $18(\mathrm{C}) ; 30$ and $48(\mathrm{~F})$ & Licitra et al. $(84,85)$ \\
\hline & $6 \cdot 8$ & 0 to 30 & Chaudhry $^{(14,15)}$ \\
\hline & 7.4 & 26 & Kopecny et al. ${ }^{\left({ }^{6}\right)}$ \\
\hline & $5-7$ & $1,4,8$ and 24 & Poos-Floyd et al. ${ }^{(13)}$ \\
\hline & $8 \cdot 0$ & $1,6,24$ and 70 & Cone et al. ${ }^{(87)}$ \\
\hline Ficin (Ficus glabrata) & $5-7$ & $1,4,8$ and 24 & Poos-Floyd et al. ${ }^{(13)}$ \\
\hline Papain (Corica papaya) & $6 \cdot 8$ & 0 to 30 & Chaudhry ${ }^{(14)}$ \\
\hline & $5-7$ & $1,4,8$ and 24 & Poos-Floyd et al. ${ }^{(13)}$ \\
\hline Bromelain (Ananas comosus) & $5-7$ & $1,4,8$ and 24 & Poos-Floyd et al. ${ }^{(13)}$ \\
\hline Protease (Aspergillus oryzae) & $5-7$ & $1,4,8$ and 24 & Poos-Floyd et al. ${ }^{(13)}$ \\
\hline
\end{tabular}

$C$, concentrate; $F$, forage. 
enzyme is 8 , which is greater than the rumen $\mathrm{pH}$. However, it has been used at both the rumen $\mathrm{pH}$ with either reduced activity $^{(88,89)}$ or reasonable response ${ }^{(14,15)}$ or higher or optimum activity at the higher $\mathrm{pH}^{(69)}$.

Protease extracted from $S$. griseus was used because its activity was comparable with the protease of B. amylophilus. Blackburn ${ }^{(90)}$ selected a pure culture of B. amylphilus strain $\mathrm{H} 18$ to study the nature of ruminal microbial proteases. This micro-organism was selected due to its ability to hydrolyse casein rapidly, its simple nutrient requirements and its utilisation of ammonia in preference to preformed amino acids and peptides. All these characteristics simplify the measurement of the endproducts of protein degradation $^{(69)}$

In the in vitro method as proposed by Krishnamoorthy et al. ${ }^{(69)}, 6.6$ enzyme units (IU) of $S$. griseus protease were used per $g$ of sample DM to break down the peptide bonds of the feedstuffs. The sample $(0.5 \mathrm{~g})$ was incubated in $40 \mathrm{ml}$ of a borate-phosphate buffer $(\mathrm{pH} 8.0)$ for $1 \mathrm{~h}$, then $10 \mathrm{ml}$ protease solution $(0.33 \mathrm{IU} / \mathrm{ml})$ were added. Roe et al. ${ }^{(82)}$ observed a fixed ratio of enzyme: $\mathrm{CP}$ and $\mathrm{pH}$ of phosphate buffer solution of 6.7 more effective for studying the enzyme degradation of feeds. These researchers assumed that all the protein that remained insoluble after an incubation of $18 \mathrm{~h}$ for concentrate feed and $48 \mathrm{~h}$ for forages was potentially rumen undegradable. The procedure then consisted of incubation of the test feed for the appropriate time and then filtration of the whole contents through a filter paper. After washing the residues with distilled water, the $\mathrm{N}$ in the residue was estimated by the Kjeldahl method. Degradability of the feedstuffs was then calculated as percentage of the total $\mathrm{CP}$ as follows:

$\operatorname{Degraded}(\mathrm{g} / \mathrm{kg})=\frac{\mathrm{CP} \text { in feed }-\mathrm{CP} \text { in feed }}{\mathrm{CP} \text { in feed }} \times 1000$.

A later modification of this method was proposed by Licitra et al. ${ }^{(85)}$ who used a fixed ratio of enzyme:true protein as determined by tungstic acid precipitation. The authors found a significant effect on the estimate of degradable $\mathrm{N}$ when compared with the original procedure. They also reported a significantly higher degradation when the buffer solution had a $\mathrm{pH}$ of 8 instead of $6 \cdot 7$. This finding differed from that of Krishnamoorthy et al. ${ }^{(69)}$ where optimum $\mathrm{pH}$ for enzyme activity was 8 . In fact, Licitra et al. ${ }^{(84)}$ suggested that the $\mathrm{pH}$ of the buffer solution should be similar to rumen conditions despite the $\mathrm{pH}$ of 8 required for the optimum enzyme activity.

A drawback in relying on the proteolytic activity of just one specific bacterium, as opposed to a group of microorganisms, is that the whole range of activities towards the different nitrogenous substrates found in the rumen may not be present in a single enzyme. Russell ${ }^{(91)}$ showed that not all species of bacteria can degrade and utilise nitrogenous substrate to the same extent. This suggests that the use of a single enzyme, even if extracted from a rumen microorganism, may not be appropriate for an accurate estimation of the total proteolytic activity of the whole rumen fluid. Luchini et al. ${ }^{(92)}$ compared the activity of a mixture of trypsin, carboxypeptidase B, chymotrypsin and carboxypeptidase A with that of the strained rumen fluid in incubations with fifteen feeds. Degradation rates using strained rumen fluid ranged from 0.008 to $0.250 / \mathrm{h}$ However, results using the enzyme mixture as the inoculum source, detected no differences in degradation rates among feeds. This indicates that the commercial enzymes employed did not mimic the activity of the strained ruminal fluid.

The use of commercial enzymes has not provided consistent results. Theoretically, there may be a problem that only one of the many microbial sources of proteases that exist in the rumen is used to prepare a purified enzyme. More serious, however, is the possibility that the protease activity present in the purified enzyme does not exist in the rumen. A comparison of protein degradation by crude extract from the rumen and by $S$. griseus protease showed variations in degradation for several feeds ${ }^{(37)}$. Furthermore, some researchers have questioned the use of any commercial protease for the estimation of ruminal protein degradation due to differences in specificity and mode of action of proteases ${ }^{(86)}$. However, Chaudhry ${ }^{(14,15)}$ has supported the use of $S$. griceus due to its ability to predict protein degradation of both purified substrates or commonly used feeds. In fact, the enzyme-based estimates for these feeds were reasonably compared with their in sacco counterparts. Therefore, this enzyme deserves further attention in standardising and validating its use to estimate rumen degradation of feeds.

\section{In vitro methods involving gas production}

A number of reports have described adaptations of the first stage of the in vitro digestibility method of Tilley \& Terry $^{(17)}$ to permit the measurement of the volume of gas produced by fermenting feedstuffs $(11,12,93-100)$. The procedure used for gas collection and measurement ranges from the use of calibrated syringes ${ }^{(11)}$ and pressure transducers ${ }^{(94)}$ to computerised monitoring ${ }^{(96)}$. Rumen fluid obtained from fistulated cattle or sheep was used for fermentation of substrates. The rumen fluid had been diluted in either bicarbonate or phosphate or bicarbonate-phosphate buffers or in a modified medium ${ }^{(93)}$ which was a complex buffer containing micro-minerals, cysteine, resazurin as well as both phosphate and bicarbonate mineral mixtures. According to Pell \& Schofield ${ }^{(96)}$, gas is produced from metabolic energy sources, and they measured the potential of different sources (monosaccharides, polysaccharides, pectin, starch, cellulose and hemicellulose) for conversion to $\mathrm{CO}_{2}$ and $\mathrm{CH}_{4}$. Gas produced has been reported to be primarily from the fermentation of digestible carbohydrates by the activity of rumen microbes. However, differences were found between researchers who suggested that gas production was also affected by other factors such as the nature of the buffer, and source and/or handling of the fermenting microorganisms ${ }^{(94,100-107)}$. This aspect requires further attention when such in vitro studies are involved to estimate degradation of ruminant feeds.

The advantage of the gas production systems is that they can be automated, thus reducing the labour input. However, automated gas production methods are expensive and may not handle large numbers of samples. While manual methods are considered cheap, they are labour intensive and restricted in capacity. The results obtained from automated 
or manual systems are dependent on several procedural details. Table $5^{(94,96-102)}$ shows the effect of several factors on gas production. In addition to these factors, the results varied with the type of system and the source, activity and consistency of the rumen fluid used ${ }^{(69)}$.

\section{In vitro method involving faeces}

It is well established that certain amounts of cellulose and hemicellulose are fermented in the large intestine, because many bacterial species in the rumen are also represented in the hind gut from where bacterial residues are subsequently passed in the faeces ${ }^{(103)}$. Therefore, the suspension of sheep faeces in buffer might be capable of acting as an inoculum for the initial fermentation of feed samples, in place of rumen liquor. In vitro digestibility determined by using sheep faeces as an inoculum correlated well with the in vivo digestibility ${ }^{(104)}$. These researchers demonstrated the potential of using microorganisms from faeces instead of rumen fluid in the twostage procedure of Tilley \& Terry ${ }^{(17)}$. Akhter et al. ${ }^{(105)}$ showed potential for cattle faeces to be used as an alternative to rumen liquor that is collected from rumenfistulated sheep for use in the in vitro digestibility assay of forages. When a $48 \mathrm{~h}$ acid pepsin digestion, the second stage of the Tilley \& Terry technique ${ }^{(17)}$, was included, the organic matter digestibility values and the ease of filtration of undigested residues were increased. They also investigated the accuracy of estimating the organic matter digestibility of eight forages determined by using rumen liquor from three sheep $(y)$ and faeces from two cows $(x)$. All regressions between sheep rumen fluid and cow faeces-based organic matter digestibility were significant $(P<0.001)$ with residual standard deviations of between \pm 0.019 and \pm 0.022 . In another study Akhter \& Hossain $^{(106)}$ concluded that fresh or frozen freeze-dried cow faeces were satisfactory and repeatable substitutes for rumen liquor as a source of micro-organisms for in vitro digestibility assay for forages. If proven to work under most conditions and satisfactorily standardised among laboratories, this method provides an opportunity to overcome the main disadvantage of the methods that require surgically prepared animals to obtain fresh rumen liquor.
Harris et al. ${ }^{(107)}$ successfully demonstrated an experiment using dairy cow faeces rather than using the traditional rumen fluid in the gas pressure transducer technique. It was observed that cumulative gas production from the test feeds for faecal inoculum showed a correlation of $R^{2} 0.95$ with data obtained from the use of rumen fluid. Nsahlai \& Umunna ${ }^{(108)}$ compared rumen fluid inocula with reconstituted sheep faeces to predict in vivo digestibility and intake and concluded that gas production using faecal inoculum was positively related to gas production using rumen fluid inoculum particularly at $48 \mathrm{~h}\left(R^{2} 0.85\right)$ of incubation. It was further confirmed by these authors that in vitro $\mathrm{DM}$ digestibility estimated using reconstituted sheep faecal inoculum had a positive correlation $\left(R^{2} 0 \cdot 88\right)$ with in vitro DM digestibility measured using rumen fluid. Since sheep faeces are much more easily obtained than rumen fluid, the faecal inoculum method would seem to have a distinct advantage in use. This advantage may be of special value as the use of fistulated animals for the purpose of nutritional studies has been criticised due to the cost and animal welfare implications of keeping fistulated animals.

\section{Summary and conclusions}

The information on rumen degradation of different feeds before their use to formulate nutritious diets for ruminant animals is essential. The in sacco method has been useful for decades to obtain this information. However, its continuous use is limited as it is laborious, inconsistent and costly. As the in sacco method requires surgically modified animals, its routine use to study degradation of ruminant feeds has undesirable implications for animal welfare and management. The in vitro methods offer advantages over the in sacco method as these are simple and speedy. However, the results from the in vitro studies were variable when compared with those from the in sacco method. While the in vitro methods involving rumen fluidbased proteases offered some interesting observations, the protein degradation rates from these methods were either greater or lower than the published estimates for the in sacco methods. These findings suggest that the faster or slow protein degradation with commercial and extracted enzymes compared with the in sacco degradation may have been due

Table 5. Factors affecting the accuracy of in vitro gas production technique involving rumen fluid (RF)

\begin{tabular}{|c|c|c|}
\hline Factor & Effect & Reference \\
\hline Sample form & $\begin{array}{l}\text { Wilting increases fermentation rate and freeze-drying and milling increases } \\
\text { gas production relative to chopped or unchopped fresh forage }\end{array}$ & Sanderson et al. ${ }^{(98)}$ \\
\hline Oven-drying samples & $\begin{array}{l}\text { Eliminates volatile constitutes from fermented substrates thus reducing } \\
\text { the indirect gas produced from the reaction of feeds with the buffer }\end{array}$ & Deaville \& Givens ${ }^{(99)}$ \\
\hline Buffer composition & $\begin{array}{l}\text { High-phosphate buffers reduce gas production by utilising protons that } \\
\text { would have been used for } \mathrm{CO}_{2} \text { production }\end{array}$ & Schofield ${ }^{(97)}$ \\
\hline RF inoculum:buffer ratio & $\begin{array}{l}\text { When greater than } 1: 2 \text {, blanks no longer truly represent the contribution } \\
\text { of the inoculum to gas production }\end{array}$ & Cone et al. ${ }^{(100)}$ \\
\hline Size of liquid-gas interface & $\begin{array}{l}\text { Determines the potential for gas saturation and solubilisation which } \\
\text { reduces gas production }\end{array}$ & Theodorou et al. ${ }^{(94)}$ \\
\hline Prevailing $\mathrm{pH}$ and temperature & Decreases gas production if below optima for cellulolytic bacteria growth & Russell \& Dombrowski ${ }^{(101)}$ \\
\hline Atmospheric pressure & $\begin{array}{l}\text { Determines actual gas volumes, yet it is often omitted such that it is } \\
\text { difficult to compare results from different laboratories }\end{array}$ & Williams $^{(102)}$ \\
\hline Stirring & $\begin{array}{l}\text { Reduces } \mathrm{CO}_{2} \text { supersaturating which causes erroneous volume } \\
\text { and pressure readings }\end{array}$ & Pell \& Schofield ${ }^{(96)}$ \\
\hline
\end{tabular}


to the variations between the enzymic activities depending upon the origin and amount of these enzymes. The gas production technique has been used as another alternative but it has been criticised as there was no firm agreement either about the gas data obtained or their relevance to the degradation of ruminant feeds. These in vitro methods require rumen fluid for the incubation of target feeds for either the estimation of degradation or to use these estimates for comparisons with the enzyme-based estimates. The use of rumen fluid is advantageous as it simulates the dynamic and specificity of the in sacco microbial degradation. However, keeping fistulated animals for obtaining rumen fluid is unacceptable on animal welfare grounds. Therefore, either rumen fluid from freshly slaughtered animals or fresh or thawed faeces could be used as alternative sources of microbes instead of rumen fluid from fistulated animals for the in vitro incubation of feeds to estimate rumen degradation (Chaudhry ${ }^{(109,110)}$ ). However, it would be essential to standardise the protocols for each method (in sacco and alternatives). This standardisation should aim to minimise the potential sources of variations among different laboratories that estimate degradation of feeds being used to formulate nutritious diets for ruminants.

\section{Acknowledgements}

R. M. thanks the Newcastle University Research Committee for a PhD studentship. There are no conflicts of interest.

\section{References}

1. Agricultural and Food Research Council (1993) Agricultural and food research council: technical committee on responses to nutrients. Nutrients requirements of ruminant animals: protein. Nutr Abst Rev 9B, 65-71.

2. National Research Council (1996) Nutrient Requirements for Beef Cattle, 7th ed. Washington, DC: National Academy Press.

3. Thomas C (2004) Feed into Milk: A New Applied Feeding System for Dairy Cows: An Advisory Manual. Nottingham, UK: Nottingham University Press.

4. Stern MD, Bach A \& Calsamiglia S (1997) Alternative techniques for measuring nutrient digestion in ruminants. J Anim Sci 75, 2256-2276.

5. Mehrez AZ \& Ørskov ER (1977) A study of the artificial fiber bag technique for determining the digestibility of feeds in the rumen. J Agric Sci Camb 88, 645-650.

6. Ørskov ER \& McDonald I (1979) The estimation of protein degradability in the rumen from incubation measurements weighted according to rate of passages. J Agric Sci Camb 92, 499-503.

7. Deaville ER, Owen E, Rymer C, Adesogan AT, Huntington JA \& Lawrence TLJ (1998) In vitro Techniques for Measuring Nutrient Supply to Ruminants. BSAS Occasional Publication no. 22. Penicuik, UK: British Society of Animal Science.

8. Little CO, Burroughs W \& Woods W (1963) Nutritional significance of soluble nitrogen in dietary proteins for ruminants. J Anim Sci 22, 358-369.

9. Wohlt JE, Sniffen CJ \& Hoover WH (1973) Measurement of protein solubility in common feedstuffs. J Dairy Sci 56, $1052-1057$.
10. Chaudhry AS \& Webster AJF (2001) Nutrient composition and the use of solubility to estimate rumen degradability of food proteins in cattle. J Sci Food Agric 81, 1077-1086.

11. Menke KH, Raab L, Salewski A, Steingass H, Fritz D \& Schneider W (1979) The estimation of the digestibility and metabolisable energy content of ruminant feedingstuffs from the gas production when they are incubated with rumen liquor in vitro. J Agric Sci 93, 217-222.

12. Krishnamoorthy UK, Rymer C \& Robinson PH (2005) The in vitro gas production technique: limitation and opportunities. Anim Feed Sci Technol 123-124, 1-7.

13. Poos-Floyd M, Klopfenstein T \& Britton RA (1985) Evaluation of laboratory techniques for predicting ruminal protein degradation. J Dairy Sci 68, 829-839.

14. Chaudhry AS (2005) Comparing two commercial enzymes to estimate in vitro proteolysis of purified and semi purified proteins. J Anim Physiol Anim Nutr 89, 403-412.

15. Chaudhry AS (2007) Enzymic and in sacco methods to estimate rumen degradation of food protein in cattle. $J$ Sci Food Agric 26, 2617-2624.

16. Tamminga S \& Williams BA (1998) In vitro techniques as tools to predict nutrient supply in ruminants. In in vitro Techniques for Measuring Nutrient Supply to Ruminants BSAS Occasional Publication no. 22, pp. 1-11 [ER Deaville, E Owen, C Rymer, AT Adesogan, JA Huntington and TLJ Lawrence, editors]. Penicuik, UK: British Society of Animal Science.

17. Tilley JMA \& Terry RA (1963) A two-stage technique for the in vitro digestion of forage crops. $\mathrm{J}$ Br Grassland Soc $\mathbf{1 8}$, 104-111.

18. Church DC (1975) Digestive Physiology and Nutrition of Ruminants. Corvallis, OR: DC Church Publishing.

19. McDonald P, Edwards RA, Greenhalgh JFD \& Morgan CA (1995) Animal Nutrition. Harlow, UK: Longman Scientific and Technical.

20. Hungate RE (1966) The Rumen and its Microbes. New York: Academic Press.

21. Chaudhry AS (2000) Microscopic studies of structure and ruminal fungal colonization in sheep of wheat straw treated with different alkalis. Anaerobe 6, 155-161.

22. Rezaeian M, Beakes GW \& Chaudhry AS (2005) Relative fibrolytic activities of anaerobic rumen fungi on untreated and sodium hydroxide treated barley straw in in vitro culture. Anaerobe 11, 163-175.

23. Schwab CG, Bozak CK, Whitehouse NL \& Mesbah MMA (1992) Amino acid limitation and flow to the duodenum at four stages of lactation. I. Sequence of lysine and methionine limitation. J Dairy Sci 75, 3486-3502.

24. Lindberg JE \& Olsson I (1983) Live weight gain in intensively reared bulls fed rations with low and high degradable protein. In IVth EAAP International Symposium on Protein Metabolism and Nutrition, Clermont-Ferrand, France, p. 243 [R Prion, M Arnal and D Bonin, editors]. Paris, France: Institut national de la recherché agronomique, European Association of Animal Production.

25. Meissner HH \& Todlenhofer U (1989) Influence of casein and glucose or starch supplementation in the rumen or abomasum on the utilization of Eragrostis curvula hay by sheep. S Afr J Anim Sci 19, 43-57.

26. Staples CR \& Lough DS (1989) Efficacy of supplemental dietary neutralizing agents for lactating dairy cows. A review. Anim Feed Sci Technol 23, 277-303.

27. Rooke JA \& Armstrong DG (1989) The importance of the form of nitrogen on microbial protein synthesis in the rumen 
of cattle receiving grass and continuous intrarumen infusions of sucrose. Br J Nutr 61, 113-120.

28. McAllan BA \& Griffith ES (1987) The effect of different sources of nitrogen supplementaion on the digestion of fibre components in the rumen of steers. Anim Feed Sci Technol 17, 65-73.

29. Ciszuk P \& Lindberg JE (1988) Responses in feed intake, digestibility and nitrogen retention in lactating dairy goats fed increasing amounts of urea and fish meal. Acta Agric Scand 38, 381-395.

30. Polan CE (1988) Update: dietary protein and microbial protein contribution. $J$ Nutr 118, 242-254.

31. Fujimaki T, Kobayashi Y, Wakita M \& Hoshino S (1992) Amino acid supplements: a least combination that increases microbial yields of washed cell suspension from goat rumen. J Anim Physiol Anim Nutr 67, 41-50.

32. Ganev G, Ørskov ER \& Smart R (1979) The effect of roughage or concentrate feeding and rumen retention time on total degradation of protein in the rumen. J Agric Sci 93, $651-659$.

33. Madsen J \& Hvelplund T (1988) The influence of different protein supply and feeding level on $\mathrm{pH}$, ammonia concentration and microbial protein synthesis in the rumen of cows. Acta Agric Scand 38, 115-125.

34. Chaudhry AS (1998) Estimation of in vitro digestibility of barley straw by using a homogenized rumen fluid and artificial saliva mixed with nitrogen and energy sources. Asian-Aust J Anim Sci 11, 13-16.

35. Ferguson JD \& Chalupa W (1989) Impact of protein nutrition on reproduction in dairy cows. Symposium: interactions of nutrition and reproduction. J Dairy Sci 72, $746-766$.

36. Johnson DE, Ward GM \& Torrent J (1992) The environmental impact of bovine somatotropin use in dairy cattle. J Environ Qual 21, 157-168.

37. Mahadevan S, Sauer FD \& Erfle JD (1987) Preparation of protease from mixed rumen micro-organisms and its use for the in vitro determination of the degradability of true protein in foodstuffs. Can J Anim Sci 67, 55-64.

38. Kohn RA \& Allen MS (1995) In vitro protein degradation of feeds using concentrated enzymes extracted from rumen contents. Anim Feed Sci Technol 52, 15-28.

39. Stern MD, Varga GA, Clark JH, Firkin JL, Huber JT \& Palmquist DL (1994) Evaluation of chemical and physical properties of feeds that affect protein metabolism in the rumen. J Dairy Sci 77, 2762-2786.

40. Broderick GA \& Merchen NR (1992) Markers for qualifying microbial protein synthesis in the rumen. $J$ Dairy Sci 75, 2618-2632.

41. Quin JI, Van der Wath JG \& Myburgh S (1938) Studies on the alimentary tract of merino sheep in South Africa. Part IV. Description of experimental technique. J Vet Sci Anim Ind 11, 341-361.

42. Van Keuren RW \& Heinemann WW (1962) Study of the nylon bag technique for in vivo estimation of forage digestibility. J Anim Sci 21, 340-345.

43. Agricultural Research Council (1984) The Nutrient Requirements of Ruminant Livestock. Supplement 1. Slough, UK: Commonwealth Agricultural Bureau.

44. Cottrill BR \& Evans PJ (1984) Estimation of Protein Degradability. Interdepartmental Protein Working Party. ARC Technical Review. Farnham Royal, Berks, UK: Agricultural Research Council, Commonwealth Agricultural Bureaux.

45. Fonseca AJM, Dias-da-Silva AA \& Ørskov ER (1997) In sacco degradation characteristics as predictors of digestibility and voluntary intake of roughages by mature ewes. Anim Feed Sci Technol 72, 205-219.

46. Rymer C \& Givens DI (2002) Relationship between patterns of rumen fermentation measured in sheep and in situ degradability and the in vitro gas production profile of the diet. Anim Feed Sci Technol 101, 31-44.

47. Verbic J, Ørskov ER, Zgajnar J, Chen XB \& ZnidarsicPongrac V (1999) The effect of method of forage preservation on the protein degradability and microbial protein synthesis in the rumen. Anim Feed Sci Technol 82, $195-212$.

48. Mahadevan S, Erfle JD \& Sauer FD (1980) Degradation of soluble and insoluble proteins by Bacteroides amylophilus protease and by rumen micro-organisms. J Anim Sci 50, 723-728.

49. De Smet AM, De Boever JL, De Brabander DL, Vanacher JM \& Boucque VC (1995) Investigation of dry matter degradation and acidotic effect of some feedstuffs by means of in sacco and in vitro incubation. Anim Feed Sci Technol 51, 297-315.

50. Djouvinov DS, Nakashima Y, Todorov N \& Pavlov D (1998) In situ degradation of feed purines. Anim Feed Sci Technol 71, 67-77.

51. Kristensen ES, Moller PD \& Hvelplund T (1982) Estimation of the effective protein degradibility in the rumen of cows using nylon bag technique combined with outflow rate. Acta Agric Scand 32, 123-127.

52. Noziere P \& Michalet-Doreau B (1996) Validation of in sacco method: influence of sampling site, nylon bag or rumen contents, on fibrolytic activity of solid-associated microorganisms. Anim Feed Sci Technol 57, 203-210.

53. Bullis DD, Haj-Manouchehri MA \& Know KL (1967) In situ nylon bags dry matter digestibility as a predictor of ration feeding value. J Anim Sci 26, 130.

54. Lopez S, Hovell FD, Manyuchi B \& Smart I (1995) Comparison of sample preparation methods for the determination of the rumen degradation characteristics of fresh and ensiled forage by nylon bag technique. Anim Sci 60, 439-450.

55. Noziere P \& Michalet-Doreau B (2000) In sacco methods. In Farm Animal Metabolism and Nutrition, pp. 233-254 [JPF D'Mello, editor]. Wallingford, UK: CAB International.

56. Cockburn JE, Dhanoa MS, France J \& Lopez S (1993) Overestimation of solubility when using Dacron bag methodology. In Proceedings of the British Society of Animal Science, Scarborough, p. 188. Penicuik, Scotland: British Society of Animal Science.

57. Huntington JA \& Givens DI (1995) The in situ technique for studying rumen degradation of feeds. A review of the procedure. Nutr Abstr Rev 65B, 63-93.

58. Nocek JE (1988) In situ and other methods to estimate ruminal protein and energy digestibility. A review. J Dairy Sci 71, 2051-2069.

59. Caton JS, Freeman AS \& Galyean ML (1988) Influence of protein supplementation on forage intake, in situ forage disappearance, ruminal fermentation and digesta passage rates in steers grazing dormant blue grama rangeland. $J$ Anim Sci 66, 2262-2271.

60. Marinucci MT, Dehority BA \& Loerch SC (1992) In vitro and in vivo studies of factors affecting digestion of feeds in synthetic fiber bags. J Anim Sci 70, 296-307.

61. Meyer JHF \& Mackie RI (1986) Microbiological evaluation of the intraruminal in sacculus digestion technique. Appl Environ Microbiol 51, 622-634.

62. Spencer D, Higgins TJV, Freer M, Dove H \& Coombe JB (1988) Monitoring the fate of dietary proteins in rumen fluid using gel electrophoresis. Br J Nutr 60, 241-247. 
63. Madsen J \& Hvelplund T (1994) Prediction of in situ protein degradability in the rumen. Results of a European ring test. Livest Prod Sci 39, 201-212.

64. Hvelplund T \& Weisbjerg MR (1998) In vitro techniques to replace in vivo methods for estimating amino acid supply. In BSAS Occasional Publication no. 22, pp. 131-144 [ER Deaville, E Owen, C Rymer, AT Adesogan, JA Huntington and TLJ Lawrence, editors]. Penicuik, UK: British Society of Animal Science.

65. Madsen J \& Hvelplund T (1985) Protein degradation in the rumen. Comparison between in vivo, nylon bag, in vitro and buffer measurements. Acta Agric Scand 25, 104-124.

66. Pichard G \& Van Soest PJ (1977) Protein solubility of ruminant feeds. In Cornell Nutrition Conference, pp. 91-98. Ithaca, New York: Cornell University.

67. Crawford RJJ, Hoover WH, Sniffen CJ \& Crooker BA (1978) Degradation of feedstuff nitrogen vs. nitrogen solubility in three solvents. J Anim Sci 46, 1768-1775.

68. Crooker BA, Sniffen CJ, Hoover WH \& Johnson LL (1978) Solvents for soluble nitrogen measurements in feedstuffs. J Dairy Sci 61, 437-447.

69. Krishnamoorthy UK, Sniffen CJ, Stern MD \& Van Soest PJ (1983) Evaluation of a mathematical model of rumen digestion and in vitro simulation of rumen proteolysis to estimate the rumen-undegraded nitrogen content of feedstuff. Br J Nutr 50, 555-568.

70. Nocek JE, Herbein JH \& Polan CE (1983) Total amino acid release rates of soluble and insoluble protein fractions and concentrate feedstuffs by Streptomyces griseus. J Dairy Sci 66, $1663-1667$.

71. Stern MD \& Satter LD (1984) Evalution of nitrogen solubility and the Dacron bag technique as methods for estimating protein degradation in the rumen. J Anim Sci $\mathbf{5 8}$, 714-724.

72. Lyttleton JW (1973) Proteins and nucleic acids. In Chemistry and Biochemistry of Herbage, pp. 63-103 [GW Butter and RW Baily, editors]. New York: Academic Press.

73. Waldo DR \& Goering HK (1979) Insolubility of proteins in ruminant feeds by four methods. J Anim Sci 49, 1560-1568.

74. Lamport DTA (1980) Structure and function of plant glycoproteins. In The Biochemistry of Plants: A Comprehensive Treatise: Carbohydrate Structure and Structure, vol. 3, pp. 501-541 [J Preiss, editor]. New York: Academic Press.

75. Krishnamoorthy U, Muscato TV, Sniffen CJ \& Van Soest PJ (1982) Nitrogen fractions in selected feedstuffs. J Dairy Sci 65, 217-225.

76. Waghorn GC (1991) Electronegativity and redox potential of rumen digesta in situ in cows eating fresh lucerne. J Agric Res 34, 359-368.

77. Hamilton BA, Ashes JR \& Camichael AW (1992) Effect of formaldehyde-treated sunflower meal on the milk production of grazing dairy cows. Aust J Agric Res 43, 379-387.

78. Aufrere J, Graviou D, Demarquilly C, Verite R, MichhaletDoreau B \& Chapoutot P (1991) Predicting in situ degradability of feed proteins in the rumen by two laboratory methods (solubility and enzymatic degradation). Anim Feed Sci Tech 33, 97-116.

79. Aufrere J \& Guerin H (1996) Critical review of chemical and enzymatic methods for the estimation of nutritive value in roughages. Ann Zootech 45, Suppl. 1, 21-38.

80. Malestein A, Klooster AT \& van't Cone JW (1988) Degradability of various types of starch by incubation with rumen fluid or with bacterial $\alpha$-amylase. J Anim Physiol Anim Nutr 59, 225-232.
81. Cone JW \& Vlot M (1990) Comparison of degradability of starch in concentrates by enzymes and rumen fluid. J Anim Physiol Anim Nutr 63, 142-148.

82. Roe MB, Chase LE \& Sniffen CJ (1991) Comparison of in vitro techniques to the in situ technique for estimation of ruminal degradation of protein. J Dairy Sci 74, 1632-1640.

83. Licitra G, Carpino S, Van Soest PJ \& Sniffen CJ (1993) Improvement of Streptomyces griseus method for degradable protein in ruminants feeds. J Dairy Sci 76, Suppl. 1, 175.

84. Licitra G, Lauria F, Schadt T, Caprpino S, Sniffen CJ \& Van Soest PJ (1997) Improvement of the Streptomyces griseus method for degradable protein in ruminant feeds. Anim Feed Sci Technol 72, 1-10.

85. Licitra G, Van Soest PJ, Schadt I, Carpino S \& Sniffen CJ (1998) Influence of the concentration of the protease from Streptomyces griseus relative to ruminal protein degradatibility. Anim Feed Sci Technol 77, 99-113.

86. Kopecny J, Vencl B, Kyselova J \& Brezina P (1989) Determination of rumen degradable protein with enzymes. Arch Anim Nutr 39, 635-645.

87. Cone JW, Van Gelder AH, Steg A \& Van Vuuren AM (1996) Prediction of in situ rumen escape protein from in vitro incubation with protease from Streptomyces griseus. Sci Food Agric 72, 120-126.

88. Chamberlain DG \& Thomas PC (1979) Prospective laboratory methods for estimating the susceptibility of feed proteins to microbial breakdown in the rumen. Proc Nutr Soc 38, 138A.

89. Terramoccia S, Puppo S, Rizzi L \& Martillotti F (1992) Comparison between in sacco and in vitro protein rumen degradability. Ann de Zootech 41, 20.

90. Blackburn TH (1968) The protease liberated from Bacteroides amylophilus strain $\mathrm{H} 18$ by mechanical disintegration. J Gen Microbiol 53, 27-36.

91. Russell JB (1984) Factors influencing competition and composition of the rumen bacterial flora. In Proceedings of the Symposium on Herbivore Nutrition in the Subtropics and Tropics, pp. 313-345 [FMC Gilchrist and RI Mackie, editors]. Craighall, South Africa: Science Press.

92. Luchini ND, Broderick GA \& Combs DK (1996) Characterization of the proteolytic activity of commercial proteases and strained ruminal fluid. J Anim Sci 74, 685-692.

93. Raab L, Cafantaris B, Jilg T \& Menke KH (1983) Rumen protein degradation and biosynthesis. Br J Nutr 50, $569-582$.

94. Theodorou KM, William AB, Dhanoa SM, McAllan BA \& France J (1994) A simple gas production method using a pressure transducer to determine the fermentation kinetics of ruminant feeds. Anim Feed Sci Technol 48, 185-197.

95. Khazaal K, Dentinho MT, Ribeiro JM \& Ørskov ER (1995) Prediction of apparent digestibility and voluntary intake of hays fed to sheep: comparison between using fiber components, in vitro digestibility or characteristics of gas production or nylon bag degradation. Anim Feed Sci Technol 61, 527-538.

96. Pell AN \& Schofield P (1993) Computerised monitoring of gas production to measure forage digestion in vitro. J Dairy Sci 76, $1063-1073$.

97. Schofield P (2000) Gas production methods. In Farm Animal Metabolism and Nutrition, pp. 209-232 [JPF D'Mello, editor]. Wallingford, UK: CAB International.

98. Sanderson R, Lister SAS \& Dhanoa MS (1997) Effect of particle size on in vitro fermentation of silages differing in dry matter content. In Proceedings of the British Society of 
Animal Science, Scarborough, p. 197. Penicuik, Scotland: British Society of Animal Science.

99. Deaville ER \& Givens DI (1998) Investigation of direct gas production from silage fermentation acids. In Proceedings of the British Society of Animal Science, Scarborough, p. 64 Penicuik, Scotland: British Society of Animal Science.

100. Cone JW, VanGelder AH \& Driehuis F (1997) Description of gas production profiles with a three-phasic model. Anim Feed Sci Technol 66, 31-45.

101. Russell JB \& Dombrowski DB (1980) Effect of pH on the efficiency of growth by pure culture of rumen bacteria in continuous culture. Appl Environ Microbiol 39, 604-610.

102. Williams BA (2000) Cumulative gas-production techniques for forage evaluation. In Forage Evaluation in Ruminant Nutrition, pp. 189-213 [DI Givens, E Owen, RFE Axford and HM Omed, editors]. Wallingford, UK: CAB International.

103. Van Soest PJ (1994) Nutritional Ecology of the Ruminant. Ithaca, New York: Cornell University Press.

104. El Shaer HM, Omed HM \& Chamberlain AG (1987) Use of faecal organisms from sheep for the in vitro determination of digestibility. J Agric Sci Camb 109, 257-259.

105. Akhter S, Owen E, Tembo SL, Theodorou MK \& Deaville ER (1999) Bovine faeces as a source of micro-organisms for the in vitro digestibility assay of forages. Grass Forage Sci 54, 219-226.
106. Akhter S \& Hossain MM (1998) Cow faeces in in vitro digestibility assays of forages. Asian-Aust J Anim Sci 11, $51-54$

107. Harris DM, Barlet A \& Chamberlain AT (1995) The use of dairy faeces rather than rumen liquor in the gas pressure transducer technique for assessing digestion kinetics in vitro. In Proceedings of the British Society of Animal Science. Penicuik, Scotland: British Society of Animal Science.

108. Nsahlai IV \& Umunna NN (1996) Comparison between reconstituted sheep faeces and rumen fluid inocula and between in vitro and in sacco digestibility methods as predictors of intake and in vivo digestibility. J Agric Sci Camb 126, 235-248.

109. Chaudhry AS (2006) In vitro degradation of forages by using rumen fluid from slaughtered cattle. In Proceedings of 57th Annual Meeting of the EAAP at Antalya, Turkey, 17-20 September, Abstract N18.91 [E Strandberg, O Moreira, C Fourichon, M Vestergaard, C Lazzaroni, M Gauly, C Wenk, W Martin-Rosset, J Hermansen and C. Thomas, editors]. Wageningen, The Netherlands: Wageningen Academic Publishers.

110. Chaudhry AS (2008) Slaughtered cattle as source of rumen fluid to evaluate supplements for in vitro degradation of grass nuts and barley straw. Open Vet Sci J 2, 16-22. 